\title{
Historic Charcoal Production in the US and Forest Depletion: Development of Production Parameters
}

\author{
Thomas J. Straka \\ School of Agricultural, Forest, and Environmental Sciences, Clemson University, Clemson, SC, USA \\ Email: tstraka@clemson.edu
}

Received 14 September 2013; revised 18 October 2013; accepted 1 November 2013

Copyright (C) 2014 by author and Scientific Research Publishing Inc.

This work is licensed under the Creative Commons Attribution International License (CC BY).

http://creativecommons.org/licenses/by/4.0/

(c) (i) Open Access

\begin{abstract}
Charcoal was the fuel of choice for the early nineteenth century for iron making and smelting of other metals in the United States. The industry involved massive amount of woodcutting and entire woodlands were depleted. The problem is somewhat exaggerated in the literature. While forest destruction tended to be quite complete near smelters and furnaces, it was generally localized near the demand for the fuel. Many authors attempt to equate furnace production to forest area depletion as one measure of environmental destruction. This is not as easy as it appears. The mathematics seems simple and uses a few basic ratios: furnace yield or bushels of charcoal needed to produce a ton of output; charcoal yield or bushels of charcoal produced from a cord of wood, and forest yield or cubic meters per ha. Different furnaces, colliers, and forests have different yields. Production parameters are critical to estimate productivity and costs. These parameters are discussed in terms of estimation problems and average expected values. This valuable information will make estimation of forest area use in charcoal production more reliable.
\end{abstract}

\section{Keywords}

Charcoal Iron Industry; Forest Depletion; Charcoal Production; Iron Plantations

\section{Introduction}

Charcoal was the fuel of choice for the early nineteenth century for iron making and smelting in the United States. Until the 1830s all iron in the United States was produced using charcoal as the fuel. After the Civil War coal and coke iron production became significant, but absolute production of charcoal iron increased until 1890 and remained significant until after World War I. The last charcoal blast furnace ceased operation in 1945 
(Shallenberg, 1975: pp. 341-342). Early iron production was an eastern US enterprise; in 1859, for example, with the minor exception of small operations in Missouri, all iron production activity was located east of the Mississippi River (Shallenberg \& Auld, 1977: p. 447).

Of course, at this same time many smelters were operating that treated ores other than iron. Silver, gold, and lead production, for example, was undergoing a boom and bust cycle across the American West. Fell (2009: p. xv) noted "What drove the settlement and resettlement of the American West in the later nineteenth and early twentieth centuries was the industrial revolution, both directly and indirectly, and the minerals Industry in the region formed an inherent part of that development.” The American West was a vast mineral empire and the technology to transform ore from the ground into a valuable commodity (metal) was the smelter and these were scattered throughout the West (Raymond, 1873b; Rohe, 1986). Like the eastern United States, western smelters were consuming massive amounts of charcoal as their preferred fuel (Brockett, 1882; Raymond, 1872).

Charcoal production involved extensive woodcutting over vast forest areas (Bining, 1973: p. 61; Gordon, 1996: pp. 40-44). Whole forests were depleted and cut to the last scrap of wood (Jacob, 1999: p. 186; Kirby, 1998: pp. 13-15). While forest destruction tended to be quite complete near smelters and furnaces, it was generally localized near the demand for the fuel (Hammersley, 1973; Straka \& Ramer, 2010; Walker, 2000: pp. 238-240). Some authors described almost complete destruction over areas as wide as 25 miles from a smelter location, but these were mainly in the sparsely forested western regions like the Great Basin (Straka \& Wynn, 2008).

How timberland did it really take to furnish fuel to a charcoal iron furnace or a smelter? The literature varies on that estimate. The units of measure within the industry were cords for wood, bushels for charcoal, and acres for land. A bushel is .035 cubic meters; a cord is 3.625 cubic meters; and an acre is .405 hectares. English units are used here to describe parameters as extensive quotations and interactions between ratios require a consistent use of measurement. All of the quoted material is in English units.

One would expect estimates of fuel efficiency, charcoal production efficiency, and woodland yields to vary. To begin, furnaces and smelters had vastly different efficiencies. Construction methods, specification, and technology varied by region and across time (Shallenberg \& Ault, 1977; Temin, 1964: pp. 62-76). Likewise, the efficiency of the collier (charcoal maker) varied (Reno, 1996: pp. 114-118). Some were paid more per bushel due to better quality (Straka \& Wynn, 2010b). Skilled colliers also had higher yields (Kemper, 1940). Other factors, like wood quality and species, impacted charcoal yield (Young \& Budy, 1979). Much charcoal was produced in kilns and kilns themselves varied in construction material, design, size, and technology. In a small region like Central Nevada, for example, kilns were constructed of brick, stone, and adobe (Straka \& Wynn, 2009, 2010a; Wynn \& Straka, 2006-2007, 2009).

Shallenberg \& Ault (1977: p. 452) estimated the maximum output for pit production of charcoal was 35 - 38 bushels per cord of wood burned. Just prior to the Civil War the use of charcoal kilns began, with their popularity increasing after the War. The maximum production of a charcoal kiln was 45 - 50 bushels (Shallenberg \& Ault, 1977: p. 453). Shallenberg \& Auld, 1977: pp. 454-456) estimated the average antebellum iron plantation's woodland yielded 30 cords of wood per acre, each cord yielded 40 bushels of charcoal, and each ton of pig iron required 180 bushels of charcoal in the furnace. Average annual output of a furnace was 1000 tons of pig iron. Thus, an average iron plantation furnace would require fuel from 150 acres of woodland per year. Another estimate of charcoal production yield in Alabama was 30 - 35 bushels per cord for pit production and 60 bushels per cord for kiln production (Armes, 2011: p. 206).

The woodlands that produced the wood for the charcoal pits and kilns also varied much in yield across the country. Old growth (original timber) might have high wood yields, but second growth might take a century to duplicate those yields. Western stands tended to be pinyon pine and juniper. Yields on these stands might be 10 cords to the acre (Lanner, 1981: pp. 117-130; Straka, 2006) and eastern hardwood stands might yield 30 cords to the acre (Gordon, 1996: pp. 27-54; Rolando, 1991: p. 16; Straka \& Ramer, 2009; Young \& Svejcar, 1999).

All these production rates add up to a measure of forest depletion. How many acres annually did it take to furnish an average furnace or smelter? Since production rates and furnace sizes varied, estimates varied. Plus, there is a temporal aspect to estimating furnace productivity, as it increased over time. The number of acres needed to produce a ton of pig iron dramatically decreased over time due to increased furnace efficiency (Williams, 2005: pp. 165-166). From 1750 to 1800 the preindustrial charcoal iron furnaces averaged outputs of 100 400 tons of pig iron annually and a ton of pig iron required 200 - 400 bushels of charcoal as fuel (50 acres of woodland to produce the charcoal). By 1850 annual output of a furnace averaged 725 - 1000 tons annually and 
the charcoal necessary to produce one ton of pig iron decreased to 150 - 250 bushels (150 acres of woodland to produce the charcoal). By 1900 furnace output reached 20,000 tons annually and each ton only required 80 - 100 bushels of charcoal (1400 acres to produce the charcoal) (Whitney, 1994).

One can find many descriptions of forest devastation caused by the charcoal industry (Muntz, 1960: p. 322; Straka, 2006; Williams, 2005). While localized forest devastation was certainly happening, many furnaces were practicing conservation and regenerating and managing harvested timberland (MacCleery, 1992; Williams, 1982). In the western United States natural regeneration was the tool and essentially as much as a century would pass before a pinyon pine stand was fully recovered from harvest (Williams, 1987). Many factors contributed to the levels of forest devastation from the charcoal industry and these are focus of the following discussion.

\section{Charcoal Fundamentals}

Charcoal is the solid residue produced when wood is "burned" in a confined space with limited air at a high temperature $\left(300^{\circ} \mathrm{C}\right.$ or $\left.572^{\circ} \mathrm{F}\right)$. The normal process of burning allows for unlimited air (oxygen) and the wood burns down to a small residue of ash. The process of carbonization or pyrolization decomposes wood instead chemically into charcoal (Toole, Lane, Arbogast, Smith, Peter, Locke, Beglinger, \& Erickson, 1961). Charcoal has always been a preferred source of heat for smelting. Charcoal burns much hotter than wood (twice the heat of seasoned wood) and more evenly and consistently than wood. Carbonization removes moisture and impurities, leaving a low ash content and low amount of trace elements like sulfur and phosphorous, meaning it produces a "clean" heat that enhances the quality and malleability of the smelter's output. Its heat is intense enough to reduce iron oxide into pig iron $\left(2600^{\circ} \mathrm{F}\right.$ to $\left.3000^{\circ} \mathrm{F}\right)$ (Williams, 2005). Plus, charcoal is much easier than wood to transport and store as it has one-third its weight and one-half its volume. Charcoal burners produced the ideal fuel for the smelting process (Birkinbine, 1883). As wood was harvested near the smelters, supply and transportation issues caused prices to rise (Gordon, 1996). So charcoal developed as its own industry, with its own set of issues like labor costs, raw material supply, and negotiations with teamsters.

Raymond (1873a: pp. 174,442) in his federal report of mining in the Great Basin region stressed the importance of charcoal as, "the only fuel used at present by the lead-smelters of the Great Basin", and that "In all smelting operations the question of fuel is one of vital importance, the cost of charcoal alone consumed in the company's works being the largest single item of expense incurred in the production of the metal”. He saw a continued rise in the cost of fuel as the timber resource was depleted.

There were two main methods of charcoal production: pit production and kiln production. Production rates differed between the two methods, but inherent differences in factors like wood species used, weather, and collier skill could impact these rates. Not just the production rates were important, charcoal quality varied also; superior charcoal did rate higher prices (Murbarger, 1956; O’Neill, 1986).

What are the characteristics of good charcoal? Chaturvedi (1943) defined it as: "Charcoal of good quality retains the grain of the wood; it is jet black in color with a shining luster in a fresh cross-section. It is sonorous with a metallic ring, and does not crush, nor does it soil the fingers. It floats in water, is a bad conductor of heat and electricity, and burns without flame”.

What factors influence the rate of burning or carbonization process? There are seven major factors (Antal \& Grønli, 2003).

First, the kind of wood has a major impact on quality. Dense wood (high specific gravity) makes the best charcoal (in terms of heat production. Heavier woods require more time for burning; sometimes a mixture of hardwood and softwood is best. Most all species of wood can be carbonized to make charcoal. Ash content will vary by species, but not significantly. However, bark has very high ash content and bark charcoal tends to be friable. So bark should not be used or at least minimized. Softwood will make useable charcoal; but it will generally be softer and more friable than that produced from hardwood. Dense wood will produce a denser, more friable charcoal (Brown, 1919).

Second, wood size is a big factor in carbonization, including length, thickness, regularity, and straightness of individual billets. Large wood pieces carbonize more slowly than smaller ones, because in larger pieces heat must be transferred to the interior and this is a slow process. Optimal size for commercial charcoal is about 25 to $80 \mathrm{~mm}$ across the grain (Svedelius, 1875).

Third, wood condition is important. Decay, knots, and defects do not make good charcoal. Fourth, moisture content of the wood placed in the pit (the charge) impacts carbonization. This moisture must be evaporated and this is accomplished by burning some of the charge and this reduces the amount of charcoal produced. Also the 
higher the moisture content, the longer the carbonization process takes and this increases costs. Green wood has a higher volume than seasoned wood, so the charcoal pit will be reduced slightly as the water evaporates. So the wood used in the charge should be properly air-dried. It is cheaper and more efficient to use air-drying, as opposed to doing it in the pit. Since some of the wood is burned in evaporating off the water, any excess water in the charge will effectively reduce the yield (Baker, 1985).

Fifth, condition of the ground is important for pit production. The ground needs to be perfectly dry, solid, level, and free from draft. Coarse sand is not a good bed for a pit as it may allow air flow. Sixth, time of year can be crucial. Usually charcoal was made in summer and early fall, after the wood from last season had dried. Seventh, weather conditions and temperature are major factors. Wind and temperature affect the rate of burn. The collier watched weather with great care. More draft was needed in rainy, humid weather, over clear, dry days or windy weather (Emrich, 1985; FAO, 1983).

\section{Method of Production}

Obviously, the methods of production will have an immense impact on both quality and quantity of production. This has already been generally discussed. The transition from pit production starting after the Civil War was largely due to gaining the benefits of increased output quality and quantity. Later, the process moved beyond kilns to retorts and other advanced processes, but, in terms of historical woodland use, the pit and kiln would be the two relevant methods.

Most charcoal was produced in charcoal pits, or meilers, as they had advantage of minimal construction cost and ease of movement. Charcoal pits and kilns are essentially the same in terms of operational features (Straka \& Wynn, 2010b). Both start with a flat, level, clean hearth. Both had a chimney in the center to ignite the fire and for draft. The pit had vertically stacked wood, perhaps in three layers. The kiln had horizontally stacked wood, also in layers. Both are ignited at the top (or possibly the bottom), burn generally downwards, and have vents at the bottom. So they are essentially the same, but for the covering. One difference is that the kiln can be ignited at the upper door with the fire following a pathway of kindling to the bottom door. One is covered with earth and charcoal dust and one has a permanent covering and two major openings (doors). Both are covered, vented woodpiles that undergo controlled burning (Kemper, 1940).

Charcoal pits in the United States generally held from 10 to 50 cords, with the average being 25 to 35 cords. Kilns can be divided into four designs: square or rectangular that held from 60 to 100 cords, round that about 50 cords, conical that held from 15 to 40 cords, and bee-hive shaped kilns that held from 20 to 50 cords (Birkinbine, 1881: pp. 66-67). They are constructed of stone, brick, or a combination of brick and stone.

The design of the beehive charcoal kiln can be traced to J. C. Cameron, an engineer from Marquette, Michigan, who developed the design in 1868. Cameron described it as a "a parabolic dome, with a base of twenty to twenty-four feet in diameter and an altitude of nineteen to twenty-two feet." He estimated the cost of construction as less than $\$ 700$. Construction likely required internal scaffolding in construction laid against the walls, as they slanted towards the top of the kiln (Notarianni, 1982: p. 42). Note that many markers and publications charcoal kilns call the style "beehive" charcoal kiln. This is often a mistake. Cameron described his beehive kiln as having a "parabolic dome", many charcoal kilns are much closer to a conical shape. While the two shapes are quite similar, there is a distinction most observers seem to ignore. It appears that the use of beehive charcoal kiln is a loosely-used term.

The design of a charcoal pit or meiler is shown in Figure 1. This charcoal pit is exposed to show the layers of wood. Figure 2 shows a rectangular charcoal kiln. They were widely used in parts of the country. Figure 3 is a beehive charcoal kiln. Notice the dome. Figure 4 is a conical charcoal kiln. Notice the top and the lack of a dome.

Figure 5 is a sketch of a burning charcoal pit with escaping gases. Nearby is a second pit ready to be covered with charcoal dust, dirt, and leaves. A collier would have several pits in the same local burning and under construction at the same time (Figure 6).

A recent archaeological project at the Panaca Summit charcoal kilns in Eastern Nevada described the operations there:

"The first layer of logs was brought in through the lower door, and set on the floor in a spoke pattern, radiating out from the center of the kiln. The next layers were stacked horizontally, and packed together as tightly as possible. A column was left open at the center, forming a chimney which was filled with brush and kindling. A similar, kindling-filled pathway connected the chimney to the lower door. The remainder of the kiln was filled, 


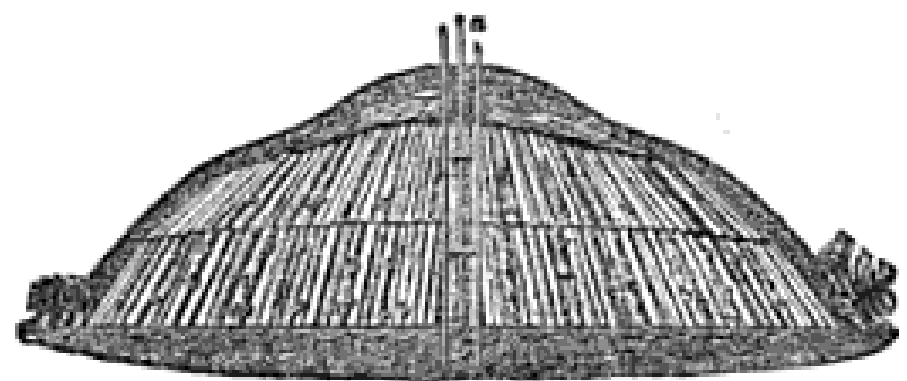

Figure 1. Typical charcoal pit on bare level flat earth with wood placed in layers for burning (Birkinbine, 1891).
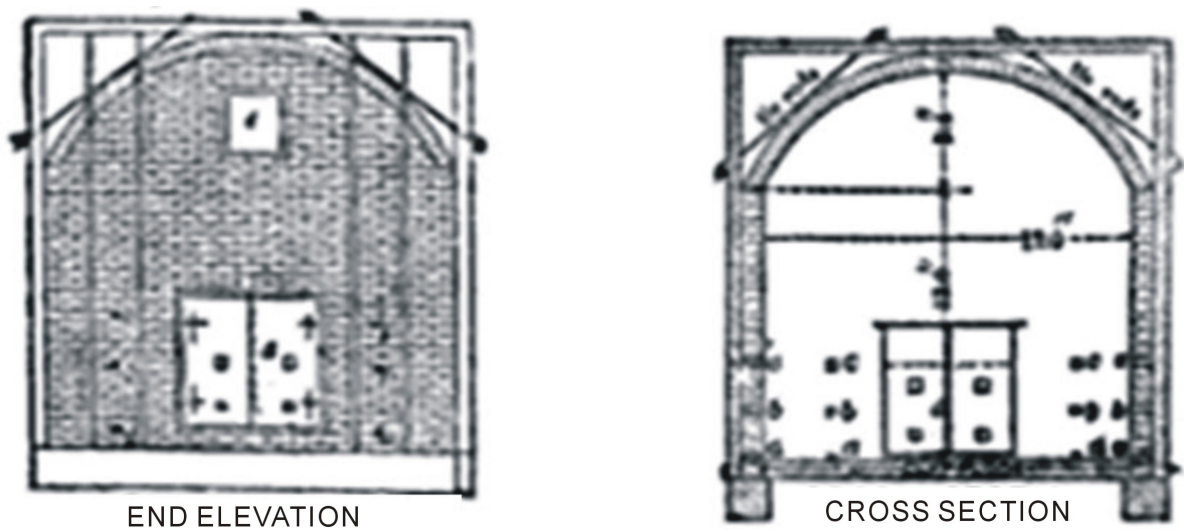

Figure 2. Rectangular charcoal kiln (Birkinbine, 1891).

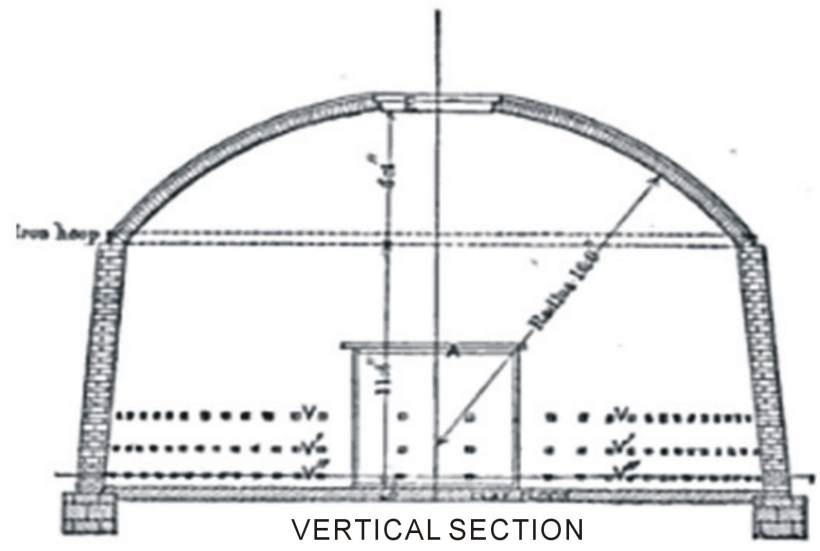

Figure 3. Beehive charcoal kiln (Birkinbine, 1891).

through the upper door as the stack grew higher. The coaling process was started by lighting the kindling at the lower door. The fire burned its way up the chimney, and more fuel was added from the top as the coals and ash settled. Eventually, the entire chimney space filled with hot coals. This ignited the logs at the top of the kiln, where the coals were hottest. The doors and chimney opening were then sealed. Airflow to the kiln was adjusted by blocking or unblocking the vents in the lower wall. This controlled the rate of combustion. Ideally, the logs burned slowly and evenly, from the top down. The complete process often took several weeks, and was constantly monitored. As long as the smoke escaping from the kiln was dark and acrid-all was well. If the smoke was light colored, or clear, the wood was burning too fast. Without quick action, there would be nothing left but a kiln full of ashes. When the coaling reached the lowermost logs, the vents were closed to extinguish the fire. After cooling for a few days, the kiln could be emptied. The circular chimney opening, seen here from inside the 


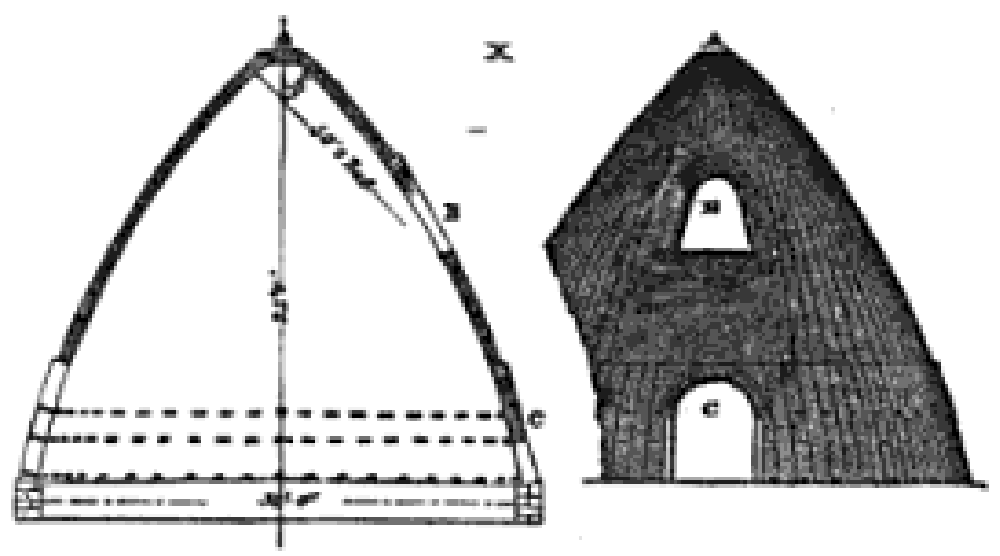

Figure 4. Conical charcoal kiln (Birkinbine, 1891).

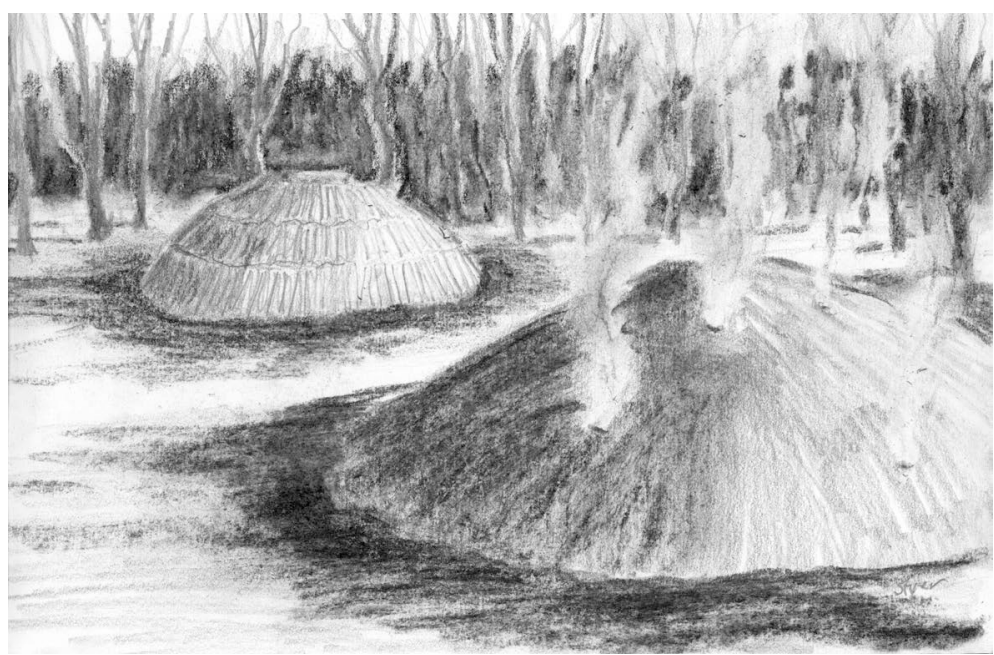

Figure 5. Two charcoal pits, one in the process of "burning" and one ready to be covered with dirt and leaves (Charcoal sketch by artist Susan Styer).

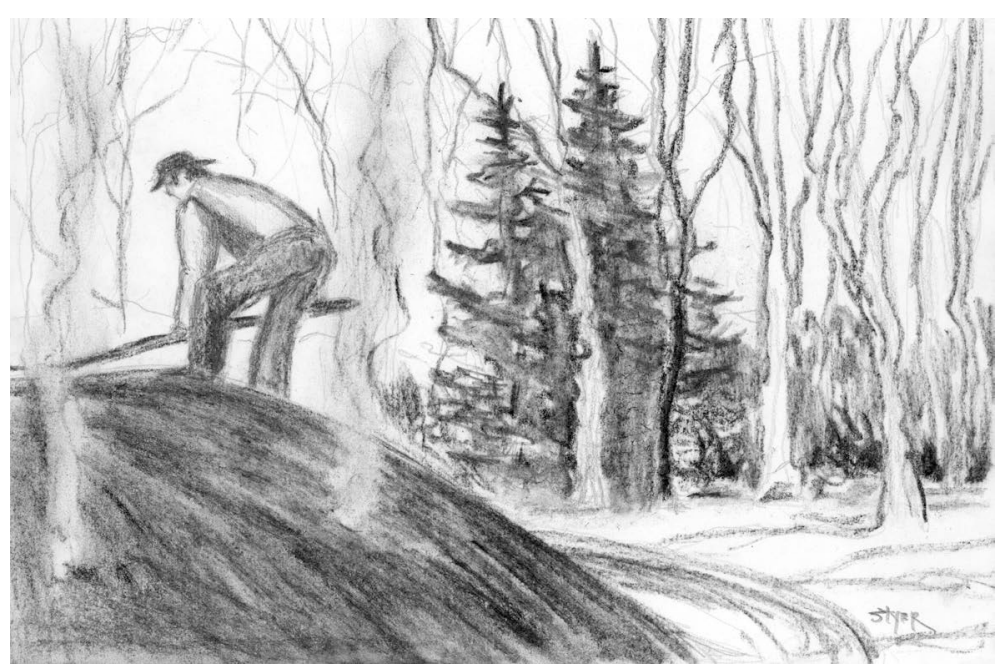

Figure 6. Charcoal production by the pit method was very labor-intensive and required 24-hour supervision by a collier (Charcoal sketch by artist Susan Styer). 
kiln, was left open when the kindling was ignited and closed during coaling. Wood was loaded and charcoal unloaded through the upper and lower doorways. The kilns were built near a slope with ramps constructed to reach the upper doors. The three rows of vents around the circumference of the kiln controlled the air flow and rate of burning. The doorways were fitted with heavy steel doors” (Zeier \& Reno, 2011: Material taken directly from historical marker created as part of project).

What were the advantages of the charcoal kiln that began to appear about 1870 (Straka \& Wynn, 2008). Charcoal kilns tended to use the beehive shape. The peak of their popularity was 1879 to 1884 (Bradley-Evans, 2006: p. 370). Various advantages have been proposed for the charcoal kiln over the pit (Birkinbine, 1879). One suggested reason was that species like Utah juniper and mountain mahogany needed the higher temperatures possible in the kiln to char (Young \& Budy, 1979). This is an unlikely reason. What were the advantages that caused charcoal kiln production to escalate over the next two decades?

Charcoal kilns were relatively expensive and never overtook the cheaper pit method of production. In $1881 \mathrm{a}$ national estimate for the iron manufacturing industry was that twice as much charcoal was produced by the pit method over the char coal kiln (Birkinbine, 1881: p. 69). The charcoal kiln does offer the advantage of increased yield. Earth covered pits yielded, on average, about 27 bushels per cord and kilns yielded about 36 bushels.

The pit or meiler charring method has two advantages: first, the charcoal pit can be located near the wood supply, minimizing the transportation of the wood to the burning site; and second, no structures are necessary, leaving only the expense of preparing a hearth and hauling wood and leaves. This method has three disadvantages: first, the wood is covered with earth, so the charcoal will always carry some dust and dirt; second, considerable wood is consumed in igniting the wood pile that yield and uniformity are reduced; and third, weather impacts the pits more than the kilns. Wind and rain can impact a pit and pits cannot be generally worked in winter.

The charcoal kiln has four advantages: first, a kiln can be operated year-round, reducing the cost and risk of stockpiling charcoal; second, the charcoal is always fresh, clean, and free from dirt; third, kilns produce increased yields; and fourth, the kilns can be located where they are easy to tend and watch, produced more uniform charcoal. This method has three disadvantages: first, the kiln is expensive to construct; second, it is likely more expensive to haul wood to the kiln, but they may be offset by the construction costs of each pit; and third, there is an expense and risk in carrying the necessary supply inventory of cut wood to keep the kilns burning (Birkinbine, 1881: pp. 71-72).

An analysis of the costs of pits versus kilns showed that kilns could reduce the cost of charcoal production by 1.5 cents per bushel, a highly significant savings. The main advantage was the wood saved by using the kiln method, since the yield is expected to be as much as 25 percent more than by using the pit method. Transportation costs both to and from the kiln and storage costs of wood for the kilns and charcoal at the furnace play a large role in the calculation (Birkinbine, 1881: pp. 66-79).

The obvious advantage of the kiln over the pit was the covering. The pit used earth, leaves, and dust. The kiln used permanent stone or brick. Both provided a protective covering that limited oxygen, but the kiln offered much better control of venting and no chance of leaks. The burning process is basically identical in the two methods; it is that covering that makes the difference. After yield, the key characteristics that differentiated the two processes were the mobility of the pit and the transportation costs. The kilns advantages were quickly recognized and they sprang up in clusters in some of the mining districts (Egleston, 1880). However, the key factor was transportation cost; often pit-produced charcoal often must be transported large distances to the furnaces and this can cause a loss of 10 to 15 percent due to rough handling of the charcoal. Thus, overall effective yield increased even more, perhaps up to a 33 percent greater yield for kilns. The kilns were expensive to construct, but cheaper operating costs with greater yields of better quality charcoal, with reduced transportation costs to the furnace, were required to incrementally exceed the charcoal pit's advantage of mobility. It would take signifycant transportation costs for the kilns to give the advantage back to pit-production (Egleston, 1881).

\section{Woodland Area Required}

There are many examples of calculations of woodland areas needed to support charcoal production. Most of the estimates for eastern woodlands were a fixed area. Most of the estimates for western woodlands were for an ever-expanding woodland area. Eastern estimates tended to be for an area surrounding the furnace that could be regenerated on a perpetual basis to permanently supply the furnace (Armes, 2011; Birkinbine, 1879; Gordon, 
1996; Hammersley, 1973; Jacob, 1999; Kemper, 1940; Muntz, 1960; Temin, 1964; Walker, 2000). Western estimates tended to be for depletion rates around a furnace (Fell, 2009; Lanner, 1981; Lanner \& Frazier, 2011; Reno, 1966; Straka; 2006; Thomas, 2007; Young \& Budy, 1979; Zeier \& Reno, 2011).

The woodland area required calculation starts with furnace productivity. How many bushels of charcoal does it take to produce one ton of output? Furnace efficiency varied. Of course, different ores also had different fuel requirements. Even within an industry, like iron, efficiency rates varied, sometimes widely. Bining (1973: p. 63) used a figure of 200 bushels per ton or iron in Pennsylvania. Joanna Furnace in Pennsylvania used a ton of fuel (about 67 bushels) to product a ton of iron (Jacob, 1999: p. 17). Shallenberg \& Ault (1977: p. 445) evaluated various furnace types in the charcoal iron industry and found efficiencies ranging from 73 to 114 bushels per ton of iron output. Western smelters had very different efficiencies. Lanner (1981: p. 124) estimated a ton of output required about 30 bushels of charcoal. Thomas (2007: p. 27) uses that same 30 bushels per ton estimate for his later depletion analysis around Ward, Nevada. Young \& Budy (1979: p. 117) estimated 25 - 35 bushels per ton. Raymond (1873a: p. 174) gives a range of 30 to 45 bushels per ton of ore, or an average of 35 bushels per ton. What is apparent is that fuel efficiency varies by type of ore, technology used, region, and type of furnace. The first variable in what seems to be a pretty simple mathematical process can be complicated and should be determined with these factors in mind.

The proper woodland yields must be used if acres depleted are to be calculated. How many cords (3.62 cubic meters) of wood will each acre (.405 ha) yield? The eastern United States iron producing region had hardwood stands that generally yielded about 30 to 35 cords to the acre. It took about 30 years of growth to produce those yields (Bining, 1973; Jacob, 1999; Straka \& Ramer, 2010; Walker, 2000). Western woodland yields were for stands were slow-growing with lower yields. Young \& Budy (1979: p. 117) cite pinyon pine-juniper yields of 1 to12 cords per acre. Lanner (1981: p. 125) uses 10 cords per acre as a good average. Thomas (2007: pp. 26-27) notes 8 cords to the acre would be space for old growth stands and that, perhaps, very mature stands yielded up to 14 cords per acre (he uses an average estimate of 10 cords per acre). Thus a second variable can be very difficult to estimate in the real world.

There is another woodland yield factor that is hardly ever explained. Woodland in the western United States took many decades to grow back to maturity. Regeneration and growth were so slow that wood supplies would likely be depleted after a decade or so of woodcutting. This happened at Eureka, Nevada. All usable wood was cut within 50 miles of town in less than a decade of time (Lanner, 1981: 125). Thus, the sparse woodland yields and slow growth rates combined to make western charcoal burning more of a forest devastation problem and wood use was usually reported in terms of a depletion rate.

However, eastern United States charcoal operations were centered on a furnace that was often run as an iron plantation, or self-sustaining enterprise. Iron plantations were some of first woodland owners to use sustained yield forest management to ensure a sustainable perpetual forest harvest (Fernow, 1882, 1885; Walker, 2000; Williams, 1989: pp. 104-110). Sustained yield, and regeneration methods to implement it, was an early subject in the forestry literature (Fernow, 1882; Hough, 1880).

Sustained yield is a fundamental concept in European forestry that flowed to North America. It involves cutting an equal amount of forest area (in terms of productivity) annually so that the same forest yield is produced into perpetuity. To achieve this, the harvested forest area is regenerated immediately so that a cycle is formed that produces forest areas with each age of timber growing simultaneously and producing the same wood yield at harvest age (Bettinger, Boston, Siry, \& Grebner, 2009; Davis, Johnson, Bettinger, \& Howard, 2001; Leuschner, 1984).

Gordon (1996: p. 40) presents an example of an eastern iron charcoal furnace. Each year the furnace burned 356,000 bushels of charcoal for fuel. Charcoal pit production yielded about 30 bushels to the cord of wood. Thus, the furnace required about 11,900 cords of wood annually. The average woodlands yield was 20 cords to the acre. So 600 acres of woodland was harvested annually to fuel the furnace. Each year 600 acres of 20-year old timber was cut and each year the land was allowed to naturally regenerate. After a 20-year cycle of this sustained yield process there would be 20 forest stands, each 600 acres in size, and each one year older than the next. That is, stand age would range from $1,2,3 \ldots$ to 20 years. The entire forest to support the furnace in perpetuity then, using sustained yield, would be 600 acres times 20 years equals 12,000 acres. Eastern furnaces did clear cut large patches for forest land, but they did it in a sustainable manner.

Sustained yield did not work in the western United States. Most of the forest stands cut were pinyon pine and juniper stands with small yields. These stands could take many decades to regenerate. So effectively a depletion 
rate around a furnace developed, so many acres were cut per year and harvesting operations would move further and further away each year. Lanner (1981: pp. 124-125) presents an example for a western furnace. Eureka, Nevada was producing 533 tons of output per day from its furnaces and this required 30 bushels of charcoal per ton of output. The furnaces consumed 16,000 bushels of charcoal daily. The yield of wood around Eureka was about 10 cords to the acre and pit charcoal production produced about 30 bushels to the cord. So roughly 530 cords of wood were used in the furnaces daily. Plus, an additional 200 cords might be needed for other fuel purposes around the mill. Just over 70 acres of pinyon pine-juniper were harvested daily and an ever-increasing circle of forest depletion developed around Eureka.

The last productivity factor that varied was charcoal production. Pit production efficiency varied due to many factors already discussed. A fair average from around the country for pit production is 30 to 35 bushels per cord. Kilns were more efficient. A fair average for kiln production is 45 to 50 , with some superior operations approaching 60 bushels per cord.

All three productivity factors showed a good degree of variability. Calculations of woodland area needed for charcoal production must take all three factors into consideration, including that variability.

\section{Conclusion}

Charcoal production had a huge impact on forest depletion in the United States. Its importance is often overlooked as it occurred as the timber industry was converting much of the nation's forests into lumber. Charcoal was the fuel for a large industry and its use did have a role in forest devastation in the late nineteenth century.

Historians often have to make calculations of the forest area impacted by activities like charcoal making. On the surface these calculations seem relatively simple. It is simple mathematics. All one needs to do is to obtain the furnace output and fuel requirements per unit of output to determine fuel requirements per unit of output; then simply use the production ratio from charcoal production to convert the fuel back to its original form of wood. Wood yields are usually known for the harvested areas, so wood used per unit of output can easily be converted to acres used per unit of output. Then total annual output will provide total annual acres of woodland consumed. There are plenty of studies that take this simple approach.

However, the three key productivity rates (furnace productivity, charcoal making productivity, and woodland yield) can be highly variable. Most authors just use published averages. The discussion above shows that all three production rates have several factors that impact their magnitude. These factors need to be part of any woodland area depletion analysis.

\section{References}

Antal, M. J., Jr., \& Grønli, M. (2003). The Art, Science, and Technology of Charcoal Production. Indian Engineering Chemistry Research, 42, 1619-1640. http://dx.doi.org/10.1021/ie0207919

Armes, E. (2011). The Story of Coal and Iron in Alabama. Tuscaloosa, AL: The University of Alabama Press.

Baker, A. J. (1985). Charcoal Industry in the U.S.A. In Symposium on Forest Products Research International-Achievements and the Future: Volume 5 (15 p). Pretoria, SA: South African Council for Scientific and Industrial Research and National Timber Research Institute.

Bettinger, P., Boston, K., Siry, J. P., \& Grebner, D. L. (2009). Forest Management and Planning. Burlington, MA: Academic Press.

Bining, A. C. (1973). Pennsylvania Iron Manufacture in the Eighteenth Century (2nd ed.). Harrisburg, PA: Pennsylvania Historical and Museum Commission.

Birkinbine, J. (1879). The Production of Charcoal for Iron Works. Transactions of the American Institute of Mining Engineers, 7, 149-158.

Birkinbine, J. (1881). Our Fuel. Journal of the United States Association of Charcoal Iron Workers, 2, 66-79.

Birkinbine, J. (1883). Charcoal as Fuel for Metallurgical Processes. Transactions of the American Institute of Mining Engineers, 11, 78-88.

Birkinbine, J. (1891). Charcoal. In Supplement to Encyclopedia Britannica, Ninth Edition, A Dictionary of Arts, Sciences, and General Literature (pp. 150-154). New York, NY: The Henry G Allen Company.

Bradley-Evans, M. S. (2006). San Francisco Mining District. In Whitley, C. K. (Ed.), From the Ground Up: the History of Mining in Utah (pp. 359-377). Logan, UT: Utah State University Press.

Brockett, L. P. (1882). Our Western Empire: Or the New West beyond the Mississippi: The Latest and Most Comprehensive 
Work on the States and Territories West of the Mississippi. Philadelphia, PA: Bradley, Garretson, and Company.

Brown, N. C. (1919). Forest Products: Their Manufacture and Use. New York, NY: John Wiley \& Sons, Inc.

Chaturvedi, M. D. (1943). The Chinese Charcoal Kiln. Indian Forestry, 69, 75.

Davis, L. S., Johnson, K. N., Bettinger, P., \& Howard, T. E. (2001). Forest Management: To Sustain Ecological, Economic, and Social Values. Long Grove, IL: Waveland Press, Inc.

Egleston, T. (1880). The Manufacture of Charcoal in Kilns. Journal of the United States Association of Charcoal Iron Workers, 1, 56-64.

Egleston, T. (1881). The Manufacture of Charcoal in Kilns. Journal of the United States Association of Charcoal Iron Workers, 2, 55-64.

Emrich, W. (1985). Handbook of Charcoal Making: The Traditional and Industrial Methods. Solar Energy R\&D in the European Community, Series E, Volume 7, Energy from Biomass. Dordrecht: D. Reidel Publishing Company.

FAO (1983). Simple Technologies for Charcoal Making. FAO Forestry Paper 41. Rome, Italy: Food and Agricultural Organization of the United Nations.

Fell, J. E., Jr. (2009). Ores to Metals: The Rocky Mountain Smelting Industry. Boulder, CO: the University Press of Colorado.

Fernow, B. E. (1882). The Yield of Wood and When to Cut It. Journal of the United States Association of Iron Charcoal Workers, 3, 19-26.

Fernow, B. E. (1885). Shall Our Charcoal in Future Be Produced from Coppice Growth or Timber Forest? Journal of the United States Association of Charcoal Iron Workers, 6, 272-281.

Gordon, R. B. (1996). American Iron: 1607-1900. Baltimore, MD: The Johns Hopkins University Press.

Hammersley, G. (1973). The Charcoal Iron Industry and Its Fuel, 1540-1750. The Economic History Review, 26, 593-613.

Hough, F. B. (1880). On the Importance of Giving Timely Attention to the Growth of Woodlands for the Supply of Charcoal for Metalurgical Uses. Journal of the United States Association of Charcoal Iron Workers, 1, 67-80.

Jacob, S. F. (1999). The History of Joanna Furnace, 1791-1999: The History of a Berks County, Pennsylvania Charcoal Iron Furnace. Geigertown, PA: Hay Creek Valley Historical Association.

Kemper, J., III. (1940). American Charcoal Making in the Era of the Cold-Blast Furnace. The Regional Review, 5, 3-14.

Kirby, E. (1998). Echoes of Iron in Connecticut's Northwest Corner. Sharon, CT: Sharon Historical Society.

Lanner, R. M. (1981). The Piñon Pine: A Natural and Cultural History. Reno: University of Nevada Press.

Lanner, R. M., \& Frazier, P. (2011). The Historic Stability of Nevada’s Pinyon-Juniper Forest. Phytologia, 93, 360-387.

Leuschner, W. A. (1984). Introduction to Forest Resource Management. New York, NY: John Wiley \& Sons, Inc.

MacCleery, D. W. (1992). American Forests: A History of Resiliency and Recovery. Durham, NC: Forest History Society.

Muntz, A. P. (1960). Forests and Iron: The Charcoal Iron Industry of the New Jersey Highlands. Geografiska Annaler, 42, 315-323. http://dx.doi.org/10.2307/520299

Murbarger, N. (1956). Charcoal: The West’s Forgotten Industry. Desert Magazine, 19, 4-9.

Notarianni, P. F. (1982). The Frisco Charcoal Kilns. Utah Historical Quarterly, 50, 40-46.

O’Neill, J. A. (1986). Central Nevada’s Charcoal Industry. Central Nevada’s Glorious Past, 9, 12-16.

Raymond, R. W. (1872). Statistics of Mines and Mining in the States and Territories West of the Rocky Mountains. Washington, DC: Government Printing Office.

Raymond, R. W. (1873a). Statistics of Mines and Mining in the States and Territories West of the Rocky Mountains. Washington, DC: Government Printing Office.

Raymond, R. W. (1873b). Silver and Gold: An Account of the Mining and Metallurgical Industry of the United States, with Reference Chiefly to the Precious Metals. New York: John B. Ford and Company.

Reno, R. L. (1996). Fuel for the Frontier: Industrial Archaeology of Charcoal Production in the Eureka Mining District, Nevada 1869-1891. Ph.D. Dissertation, Reno: University of Nevada.

Rohe, R. (1986). Man and the Land: Mining’s Impact on the Far West. Arizona and the West, 28, 299-338.

Rolando, V. R. (1991). 19th-Century Charcoal Production in Vermont. The Journal of the Society for Industrial Archeology, 17, 15-36.

Shallenberg, R. H. (1975). Evolution, Adaptation and Survival: The Very Slow Death of the American Charcoal Iron Industry. Annals of Science, 32, 341-358. http://dx.doi.org/10.1080/00033797500200331

Shallenberg, R. H., \& Ault, D. A. (1977). Raw Materials Supply and Technological Change in the American Charcoal Iron 
Industry. Technology and Culture, 18, 436-466. http://dx.doi.org/10.2307/3103901

Straka, T. J. (2006). Tom Straka on Chris Kreider’s “Ward Charcoal Ovens” and Nevada’s carbonari. Environmental History, 11, 344-349. http://dx.doi.org/10.1093/envhis/11.2.344

Straka, T. J., \& Ramer, W. C. (2009). Fuel for the Charcoal-Iron Furnaces. Pennsylvania Forests, 100, 10-11.

Straka, T. J., \& Ramer, W. C. (2010). History on the Road: Hopewell Furnace. Forest History Today, 58-62.

Straka, T. J., \& Wynn, R. H. (2008). History on the Road: Charcoal and Nevada’s Early Mining Industry. Forest History Today, 63-66.

Straka, T. J., \& Wynn, R. H. (2009). Charcoal Kilns of Eureka and White Pine Counties. Central Nevada's Glorious Past, 28, 9-14.

Straka, T. J., \& Wynn, R. H. (2010a).Western Nevada and Eastern California Charcoal Kilns. Central Nevada’s Glorious Past, 29, 7-11.

Straka, T. J., \& Wynn, R. H. (2010b). Pit Production of Charcoal for Nevada's Early Smelters. Central Nevada's Glorious Past, 29, 12-16.

Svedelius, G. (1875). Hand-Book for Charcoal Burners. New York: John Wiley \& Son.

Temin, P. (1964). Iron and Steel in Nineteenth-Century America: An Economic Inquiry. Cambridge, MA: MIT Press.

Thomas, N. D. (2007). Pinyon-Juniper Woodland Resource Depletion at the Ward Historic Mining District, 1872-1888. Nevada Archeologist, 22, 23-32.

Toole, A. W., Lane, P. H., Arbogast Jr., C., Smith, W. R., Peter, R., Locke, E. G., Beglinger, E., \& Erickson, E. C. O. (1961). Charcoal Production, Marketing, and Use. Report No. 2213. Madison, WI: USDA Forest Service, Forest Products Laboratory.

Walker, J. E. (2000). Hopewell Village: The Dynamics of a Nineteenth-Century Iron-Making Community. Fort Washington, PA: Eastern National.

Williams, C. E. (2005). Environmental impact. In K. Hillstrom, \& L. C. Hillstrom (Eds.), The Industrial Revolution in America: Iron and Steel (pp. 157-182). Santa Barbara, CA: ABC-CLIO.

Williams, M. (1982). Clearing the United States forests: Pivotal Years 1810-1860. Journal of Historical Geography, 8, $12-16$. http://dx.doi.org/10.1016/0305-7488(82)90242-0

Williams, M. (1987). Industrial Impacts on the Forests of the United States, 1860-1920. Journal of Forest History, 31, 108-121.

Williams, M. (1989). Americans and Their Forests: A Historical geography. Cambridge: Cambridge University Press.

Whitney, G. G. (1994). From Coastal Wilderness to Fruited Plains: A History of Environmental Change in Temperate North America, 1500 to the Present. Cambridge, UK: Cambridge University Press.

Wynn, R. H., \& Straka, T. J. (2009). Lincoln County Charcoal Kilns. Central Nevada’s Glorious Past, 28, 5-8.

Wynn, R. H., \& Straka, T. J. (2006-2007). Charcoal Kilns of the Hot Creek Range. Central Nevada's Glorious Past, 27, 5-13.

Young, J. A., \& Budy, J. D. (1979). Historical Use of Nevada’s Pinyon-Juniper Woodlands. Journal of Forest History, 23, 112-121.

Young, J. A., \& Svejcar, T. J. (1999). Harvesting Energy from 19th Century Great Basin Woodlands. In S. B. Monsen, \& R. Stevens (Eds.), Proceedings: Ecology and Management of Pinyon-Juniper Communities Within the Interior West (pp. 47-50). Proceedings RMRS-P-9. Fort Collins, CO: USDA Forest Service, Rocky Mountain Research Station.

Zeier, C. D., \& Reno, R. (2011). The Panaca Summit Charcoal Kilns, Lincoln County, Nevada: A Historic Context and an Archaeological Inventory. Clinton, TN: Zeier \& Associates, LLC. 